Vol. 10(14), pp. xxx-xxx, 30 July, 2015

DOI: $10.5897 /$ SRE2015.6268

Article Number:xxxxxx

ISSN 1992-2248

Copyright(C2015

Scientific Research and Essays

Author(s) retain the copyright of this article

http://www.academicjournals.org/SRE

\title{
Purification and biochemical characterization of extracellular manganese peroxidase from Ganoderma lucidum IBL-05 and its application
}

\author{
Muhammad Bilal ${ }^{\star}$, Muhammad Asgher, Muhammad Ramzan \\ Industrial Biotechnology Laboratory, Department of Biochemistry, University of Agriculture, Faisalabad, Pakistan.
}

Received 28 May, 2015; Accepted 10 July, 2015

\begin{abstract}
In this study an extracellular manganese peroxidase (MnP) was isolated from culture filtrate of an indigenous fungal strain Ganoderma lucidum IBL-05 under static conditions using wheat bran as substrate. The enzyme was purified by applying successively ammonium sulphate precipitation, dialysis, ion exchange and gel filtration chromatographic techniques. Purification procedure resulted in 3.43-fold purification with corresponding specific activity of $539.59 \mathrm{Umg}{ }^{-}{ }^{1}$. The purified MnP elucidated single band in $43 \mathrm{kDa}$ region on sodium dodecyl sulphate polyacrylamide gel electrophoresis (SDSPAGE). The purified MnP showed optimum activity at pH 5 and $40^{\circ} \mathrm{C}$ temperature. The $K_{m}$ and $V_{\max }$ for $\mathrm{MnP}$ toward $\mathrm{MnSO}_{4}$ as a substrate were found to be $65.5 \mathrm{mM}$ and $640 \mathrm{UmL}^{-1}$, respectively. It was observed that MnP activity enhanced by $\mathrm{Mn}^{2+}$ and $\mathrm{Cu}^{2+}$ and inhibited in the presence of $\mathrm{Zn}^{2+}, \mathrm{Fe}^{2+}$, EDTA and Cysteine to various extents with $\mathrm{Hg}^{2+}$ (most inhibitory). The purified MnP efficiently catalyzed the transformation of different synthetic textile dyes (Sandal-reactive dyes). Characterization revealed that $\mathrm{MnP}$ isolated from G. Iucidum have potential to be used for myriad industrial and biotechnological applications.
\end{abstract}

Key words: Manganese peroxidase, Ganoderma lucidum IBL-05, purification, characterization, kinetics, dye decolorization.

\section{INTRODUCTION}

Significant efforts have been made on filamentous fungal biotechnology in recent years in order to obtain value added products such as enzymes, chemicals, liquid biofuel, secondary metabolites and spores (Reina et al., 2013). White-rot basidiomycetes are the principal organisms that secrete a unique set of extracellular oxidoreductases comprising lignin peroxidase (LiP;
Ec1.11.1.14), manganese peroxidase (MnP; EC 1.11.1.13) and laccase (Lac; EC 1.10.3.2). These catalysts are known with remarkable potential to depolymerize lignin and various environmental pollutants such as polycyclic aromatic hydrocarbons, synthetic dyes and cholorophenols (Du et al., 2015). Different white rot fungi (WRF) secrete different set of lignin mineralizing 
enzymes (LMEs) and each fungus secretes one or more of the three enzymes essential for lignin degradation (Levin et al., 2008). Besides, some versatile peroxidases (VP; EC.1.11.1.16) with combined LiP and MnP catalytic properties have also been reported (Morgenstern et al., 2008).

Due to their interesting catalytic properties, MnPs have gained considerable interest in various industrial areas. The most intensively studied applications have included bioremediation, biomass delignification, oxidation of organic pollutants, bio sensing, textile, animal feed, cosmetics, detergent manufacturing, paper and pulp, transformation of antibiotics and steroids etc (Sylvia et al., 2015). MnP (EC 1.11.1.7) is a lignin-modifying glycoprotein synthesized by wood-colonizing basidiomycetes during secondary metabolism. It catalyzes phenolic compounds to phenoxy radicals by oxidation of $\mathrm{Mn}^{2+}$ to reactive $\mathrm{Mn}^{3+}$ in $\mathrm{H}_{2} \mathrm{O}_{2}$ dependent enzymatic reaction (Ferhan et al., 2012). However, some low molecular weight mediators can increase the substrate range of $\mathrm{MnPs}$ to non-phenolic structures (Giardina et al., 2000). Further, many proteins acting synergistically with $\mathrm{MnPs}$, has expanded the role of these enzymes in fungal lignolysis (Hilden et al., 2000).

Among WRF, Ganoderma lucidum is considered as the most commonly used organism in biodegradation studies due to its good ligninolytic properties, fast growth potentials, and environmental-friendly nature (Batool et al., 2013). Keeping in view the extensive industrial applications of MnP, the present study was accomplished with an objective to purify and characterize the extracellular $\mathrm{MnP}$ from an indigenous WRF strain $G$. lucidum IBL-05 and then tested it for its ability to decolorize different textile dyes.

\section{MATERIALS AND METHODS}

\section{Fungal culture and inoculum development}

For inoculum development, the indigenously isolated G. lucidum IBL-05 strain was grown in Kirk's basal nutrient medium (Tien and Kirk, 1988) in Erlenmeyer flask $(250 \mathrm{ml})$ that was supplemented with Millipore filtered $1 \%$ glucose. Prior to sterilization, the medium was adjusted at $\mathrm{pH} 4.5$ with $1 \mathrm{M} \mathrm{NaOH} / 1 \mathrm{M} \mathrm{HCl}$ and inoculated with spores of $\mathrm{G}$. lucidum IBL-05 from slant culture. The inoculated flask was incubated $(120 \mathrm{rpm})$ at $30^{\circ} \mathrm{C}$ for 5 to 7 days to get homogenous spore suspension of the fungus $\left(1 \times 10^{6}-10^{8} \mathrm{spores} / \mathrm{ml}\right)$ and used as inoculum.

\section{Production and extraction of MnP}

Triplicate conical flasks containing $5 \mathrm{~g}$ semi-solid wheat bran were autoclaved and inoculated with $5 \mathrm{ml}$ homogenous inoculum (Ramzan et al., 2013). The inoculated flasks were allowed to ferment at $30^{\circ} \mathrm{C}$ in a temperature controlled incubator for 5 to 7 days at $\mathrm{pH}$ 4.5. After growth, sterile samples were taken after every $24 \mathrm{~h}$ and $\mathrm{MnP}$ activity was monitored. When MnP activity was peaked to a maximum level, the fermented biomass was harvested by adding $100 \mathrm{ml}$ distilled water, filtered, centrifuged (Ependorf
5415C, Germany) and clear supernatant was assayed for MnP enzyme and stored at $4^{\circ} \mathrm{C}$ in refrigerator for further characterization. All experiments were carried in triplicate to avoid the discrepancy in results.

\section{Determination of MnP activity and protein contents}

The MnP activity was determined by monitoring the formation of $\mathrm{Mn}^{3+}$-malonate complexes at $270 \mathrm{~nm}\left(\varepsilon_{270}=11570 \mathrm{M} \mathrm{cm}^{-1}\right.$, Wariishi et al., 1992). Assay mixture contained $1 \mathrm{ml}$ of $1 \times 10^{-3} \mathrm{M} \mathrm{MnSO}_{4}, 1 \mathrm{ml}$ of $50 \times 10^{-3} \mathrm{M}$ sodium malonate buffer $(\mathrm{pH} 4.5)$ and $0.5 \mathrm{ml}$ of $\mathrm{H}_{2} \mathrm{O}_{2}$ in combination with $0.1 \mathrm{ml}$ enzyme solution. Absorbance of each sample was measured Spectrophotometrically (HALO DB-20). The protein concentration was estimated according to Bradford method (1976) using bovine serum albumin (BSA) as a standard.

\section{Purification of MnP}

All the purification steps were conducted below $4^{\circ} \mathrm{C}$. Briefly, crude $\mathrm{MnP}$ extract obtained from 5 days old culture of G. lucidum IBL-05 was centrifuged at $3,000 \times \mathrm{g}$ for $15 \mathrm{~min}$. The cell-free supernatant was saturated (up to $35 \%$ ) by gradual addition of ammonium sulphate and kept for overnight at $4^{\circ} \mathrm{C}$. The resulting precipitate, thus obtained was recovered $\left(3,000 \times \mathrm{g}\right.$ for $20 \mathrm{~min}$ at $\left.4^{\circ} \mathrm{C}\right)$ and supernatant was again saturated by adding ammonium sulfate (up to $65 \%$ ), allowed to stand overnight at $4^{\circ} \mathrm{C}$, centrifuged and pellets were dissolved in $50 \mathrm{mM}$ Sodium Malonate buffer ( $\mathrm{pH} \mathrm{4.5).} \mathrm{The}$ solution was kept in dialysis bag and dialyzed against the same buffer, after sealing it securely and finally, dialyzate was freeze dried. The dialyzate obtained was submitted to ion-exchange chromatography using diethyl amino ethyl (DEAE) cellulose column, equilibrated with phosphate buffer $(100 \mathrm{mM}$; $\mathrm{pH} 6.5)$ for $24 \mathrm{~h}$ and eluted with 0 to $1.0 \mathrm{M}$ linear gradient of $\mathrm{NaCl}$ at a flow rate of 0.5 $\mathrm{ml} / \mathrm{min}$. The MnP active fractions were pooled and loaded onto Sephadex-G-100 column $(10 \times 300 \mathrm{~mm})$. Up to 30 positive fractions $(1 \mathrm{ml})$ with flow rate of $0.3 \mathrm{ml} / \mathrm{min}$ were collected and absorbance was measured at $280 \mathrm{~nm}$ (Zeng et al., 2013).

\section{Gel electrophoresis and staining}

The MnP purification was confirmed by sodium dodecyl sulphatepolyacrylamide gel electrophoresis (SDS-PAGE) following the method of Laemmli (1970). The molecular mass of MnP was approximated after gel staining with Coomassie Brilliant Blue G-250 followed by calibration against standard protein markers (Sigma, USA), ranging from 17-170 kDa.

\section{Characterization of purified MnP}

Effect of $\mathrm{pH}$ on $\mathrm{MnP}$ activity was investigated by incubating enzyme for $15 \mathrm{~min}$ at varying $\mathrm{pH}$ values (3 to 10). For stability studies the enzyme was pre-incubated at varying $\mathrm{pH}$ for $1 \mathrm{~h}$. MnP activities were also determined at various temperatures between 30 and $70^{\circ} \mathrm{C}$ under optimal $\mathrm{pH}$ values. The enzyme was incubated for 15 min at varying temperatures before running the enzyme assay. For thermal-stability the enzyme was incubated at different temperatures for $1 \mathrm{~h}$ without substrate before carrying out $\mathrm{MnP}$ assay. $K_{m}$ and $V_{\max }$ for the purified enzyme were calculated using the Lineweaver Burk transformation of Michaelis-Menten equation. The standard quartz cuvettes of $1 \mathrm{~mm}$ path length were used to calculate the values of kinetic parameters. The enzyme was incubated for $15 \mathrm{~min}$ at $30^{\circ} \mathrm{C}$ in sodium malonate buffer of $\mathrm{pH} 4.5$ before carrying out standard enzyme assay protocol. Lineweaver-Burk (Double reciprocal) plot was generated with 
Microsoft Excel Windows updated version 7 via nonlinear regression analysis using different concentrations $(0.1$ to $1.0 \mathrm{mM})$ of manganese sulphate as substrate at optimum $\mathrm{pH} 5$ and $40^{\circ} \mathrm{C}$ temperature. The effects of various modulators $\left(\mathrm{Mn}^{2+}, \mathrm{Zn}^{2+}, \mathrm{Co}^{2+}\right.$, $\mathrm{Cu}^{2+}, \mathrm{Fe}^{2+}, \mathrm{Hg}^{2+}, \mathrm{K}^{+}$, Ethylene diamine tetra acetic acid (EDTA) and cysteine) on enzyme activities were tested in the concentration range of 5 to $20 \mathrm{mM}$. Enzyme activities measured without any modulator was considered as $100 \%$ (Zeng et al., 2013).

\section{Dyes and decolorization studies}

Three dyes namely Sandal-fix Red $\mathrm{C}_{4} \mathrm{BLN}(\lambda \max : 540 \mathrm{~nm})$, Sandalfix Turq Blue GWF ( $\lambda$ max: $664 \mathrm{~nm}$ ) and Sandal-fix Black CKF ( $\lambda \max : 598 \mathrm{~nm}$ ) were used to investigate the decolorization potential of purified MnP. For this, MnP solution was transferred to triplicate Erlenmeyer flasks $(500 \mathrm{ml})$ containing $100 \mathrm{ml}$ of individual dye solution $(0.1 \mathrm{mg} / \mathrm{ml})$ in combination with Na-malonate buffer (50 $\mathrm{mM} ; \mathrm{pH}$ 4.5). Flasks were incubated in rotary shaker (SanyoGallenkamp, UK) at $40^{\circ} \mathrm{C}$ for $12 \mathrm{~h}$. The flasks content were filtered, centrifuged $(8,000 \times \mathrm{g}, 10 \mathrm{~min})$ and dye removal was monitored spectrophotometrically (HALO DB-20) at respective wavelengths. The decolorization efficiency was calculated using relation (Equation 1).

Decolorization $(\%)=\frac{A i-A t}{A i} \times 100$

Where, $\mathrm{A} i$ and $\mathrm{A} t$ are representing absorbance at zero and time $t$.

\section{Statistical analysis}

Mean and standard deviation (SD) of the results based on three independent experiments were calculated using Microsoft Excelsoftware (Microsoft) and the standard error (SE) values were displayed as $\mathrm{Y}$-error bars in figures.

\section{RESULTS AND DISCUSSION}

\section{Production of MnP}

In this study, a locally isolated fungal strain, G. lucidum IBL -5was exploited for ligninolytic enzyme (Lip, MnP and laccase) production potential in solid state medium of wheat bran under pre-optimized growth conditions such as moisture, $50 \%$; substrate, $5 \mathrm{~g}$; $\mathrm{pH}, 5.5$; temperature, $30^{\circ} \mathrm{C}$; carbon source, $2 \%$ glucose; nitrogen source, $0.02 \%$ yeast extract; $\mathrm{C}: \mathrm{N}$ ratio, 25:1; fungal spore suspension, $5 \mathrm{ml}$ and fermentation time period, 5 days (Ramzan et al., 2013). The enzyme extract contained 576.3, 717.7 and 323.2 $\mathrm{UmL}^{-1}$ of LiP, MnP and laccase, respectively.

\section{Purification of MnP}

A sequential four-step purification procedure involving ammonium sulphate fractionation, dialysis, DEAEcellulose ion exchange and G-100 sephadex gel permeation chromatography was employed for the purification of MnP. A mixture of crude ligninolytic extract obtained from five days incubated culture $(300 \mathrm{ml})$ of $G$. lucidum on wheat bran was purified to homogeneity as summarized in Table 1. The MnP was completely salted out at $65 \%$ saturation with $\left(\mathrm{NH}_{4}\right)_{2} \mathrm{SO}_{4}$ to 1.73 fold purification with specific activity of $273.01 \mathrm{U} / \mathrm{mg}$. After ammonium sulphate precipitation, the crude extract was applied to ion exchange chromatography. The elution pattern on the DEAE-cellulose column showed two protein peaks at $280 \mathrm{~nm}$ (Figure 1). The fractions with high MnP activities were pooled, concentrated and loaded onto a Sephadex G-100 column. In Figure 2 it was clearly indicated that the MnP eluted in a single prominent peak on gel filtration chromatography. At the end of fourth purification step, the enzyme had been 3.43-fold purified with corresponding specific activity of $539.59 \mathrm{U} / \mathrm{mg}$. The purified MnP appeared as a single band in $43 \mathrm{KDa}$ region on SDS-PAGE analysis (Figure 3 ), suggesting that the enzyme was a monomeric protein. The MnPs also secreted in a multiple isoform with distinct structural configuration and molecular mass. The molecular masses of $\mathrm{MnP}$ vary from 32 to $75 \mathrm{kDa}$ (Asgher et al., 2013).

\section{Characterization of purified MnP}

\section{Effect of $\mathrm{pH}$ on MnP activity and stability}

The $\mathrm{pH}$ profile for purified $\mathrm{MnP}$ has been illustrated in Figure 4. The MnP displayed maximum activity at optimum $\mathrm{pH} 5$; beyond this $\mathrm{pH}$ value a marked decreasing trend in the activity was observed. Moreover, the purified $\mathrm{MnP}$ was fairly stable over a wide range of $\mathrm{pH}(4-6)$ at incubated time of $1 \mathrm{~h}, \mathrm{pH}$ above 6 caused inactivation of the enzyme irrespective of incubation time. In previous studies, maximum activity of $\mathrm{MnP}$ from different WRF has been reported in the $\mathrm{pH}$ range of 4.5 to 6.5 (de Oliveira et al., 2009). MnP isolated from solidstate culture of corncobs by Lentinula edodes exhibited optimum activity at pH 4.5 (Boer et al., 2006); whereas, $\mathrm{MnP}$ from $\mathrm{S}$. commune IBL-06 was optimally active at $\mathrm{pH}$ 5 (Asgher et al., 2013).

\section{Effect of temperature on MnP activity and stability}

The MnP activity against temperature curve shown in Figure 5, the plot indicated that initial rise of temperature up to $40^{\circ} \mathrm{C}$ increased the activity as well as stability of the $\mathrm{MnP}$. Further rise of temperature caused decrease of activity and stability as well due to denaturation of enzyme at elevated heat. The optimum temperature for purified MnP was found to be $40^{\circ} \mathrm{C}$. The purified $\mathrm{MnP}$ showed fascinating thermal-stability up to $50^{\circ} \mathrm{C}$ without dropping much of its activity, which would be an attractive and desirable feature for a variety of industrial processes. However, MnP lost almost $50 \%$ of its activity when 
Table 1. Purification summary of MnP produced by G. Iucidum IBL-05 in solid state fermentation.

\begin{tabular}{|c|c|c|c|c|c|c|}
\hline Step & Purification steps & $\begin{array}{c}\begin{array}{c}\text { Total } \\
\text { volume }\end{array} \\
(\mathrm{ml}) \\
\end{array}$ & $\begin{array}{l}\text { Enzyme } \\
\text { activity } \\
\left(\mathrm{U} \mathrm{ml}^{-1}\right)\end{array}$ & $\begin{array}{c}\begin{array}{c}\text { Protein } \\
\text { contents }\end{array} \\
\left(\mathrm{mg} \mathrm{ml}^{-1}\right)\end{array}$ & $\begin{array}{c}\text { Specific } \\
\text { activity } \\
\left(\mathrm{U} \mathrm{mg}^{-1}\right)\end{array}$ & $\begin{array}{c}\text { Purification } \\
\text { fold }\end{array}$ \\
\hline 1 & Crude enzyme & 300 & 717.4 & 4.34 & 132.32 & 1 \\
\hline 2 & Ammonium Sulphate ppt. & 22 & 613.7 & 2.45 & 273.01 & 1.73 \\
\hline 3 & Dialysis & 21 & 598.09 & 2.13 & 390.91 & 1.95 \\
\hline 4 & DEAE-cellulose & 12 & 584.3 & 1.68 & 420.34 & 2.78 \\
\hline 5 & Sephadex G-100 & 9 & 569.6 & 0.9 & 539.59 & 3.43 \\
\hline
\end{tabular}

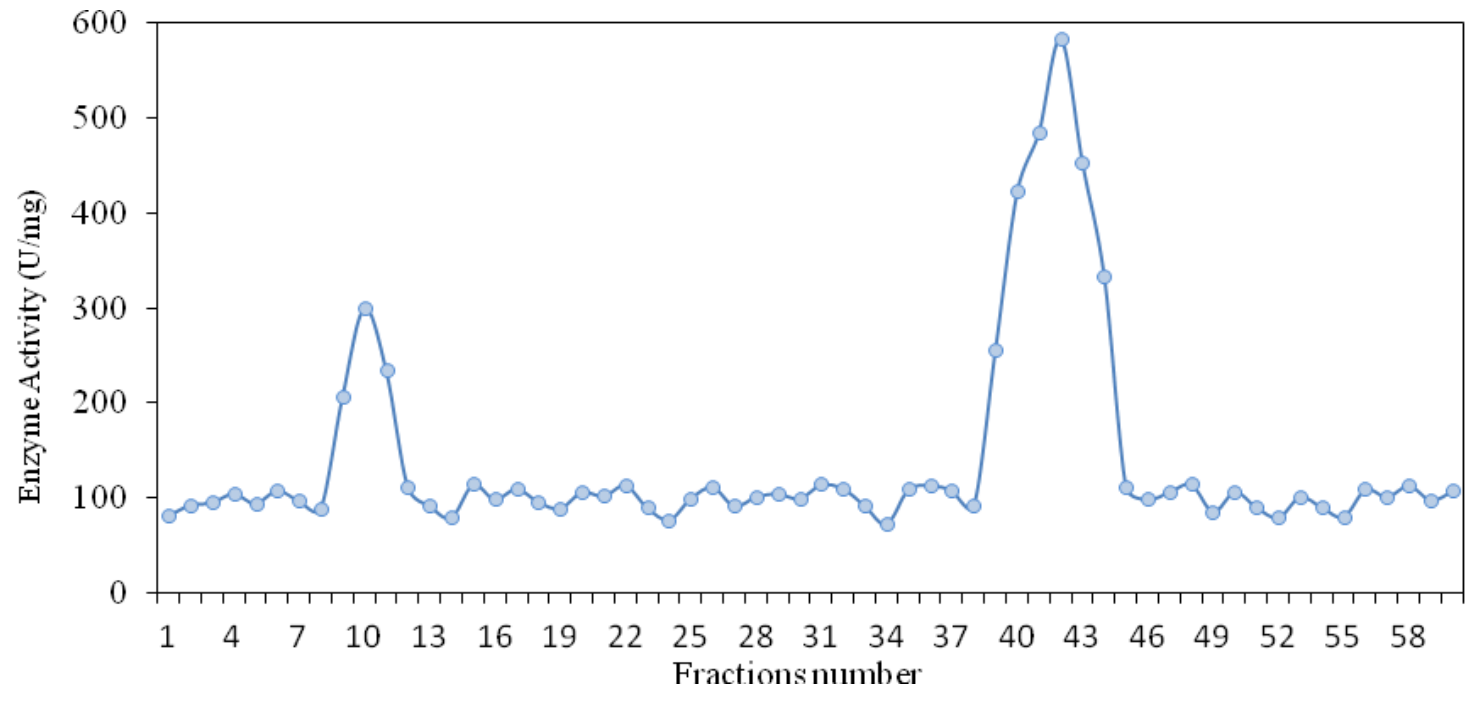

Figure 1. Ion exchange chromatographic purification profile for MnP from G. lucidum.

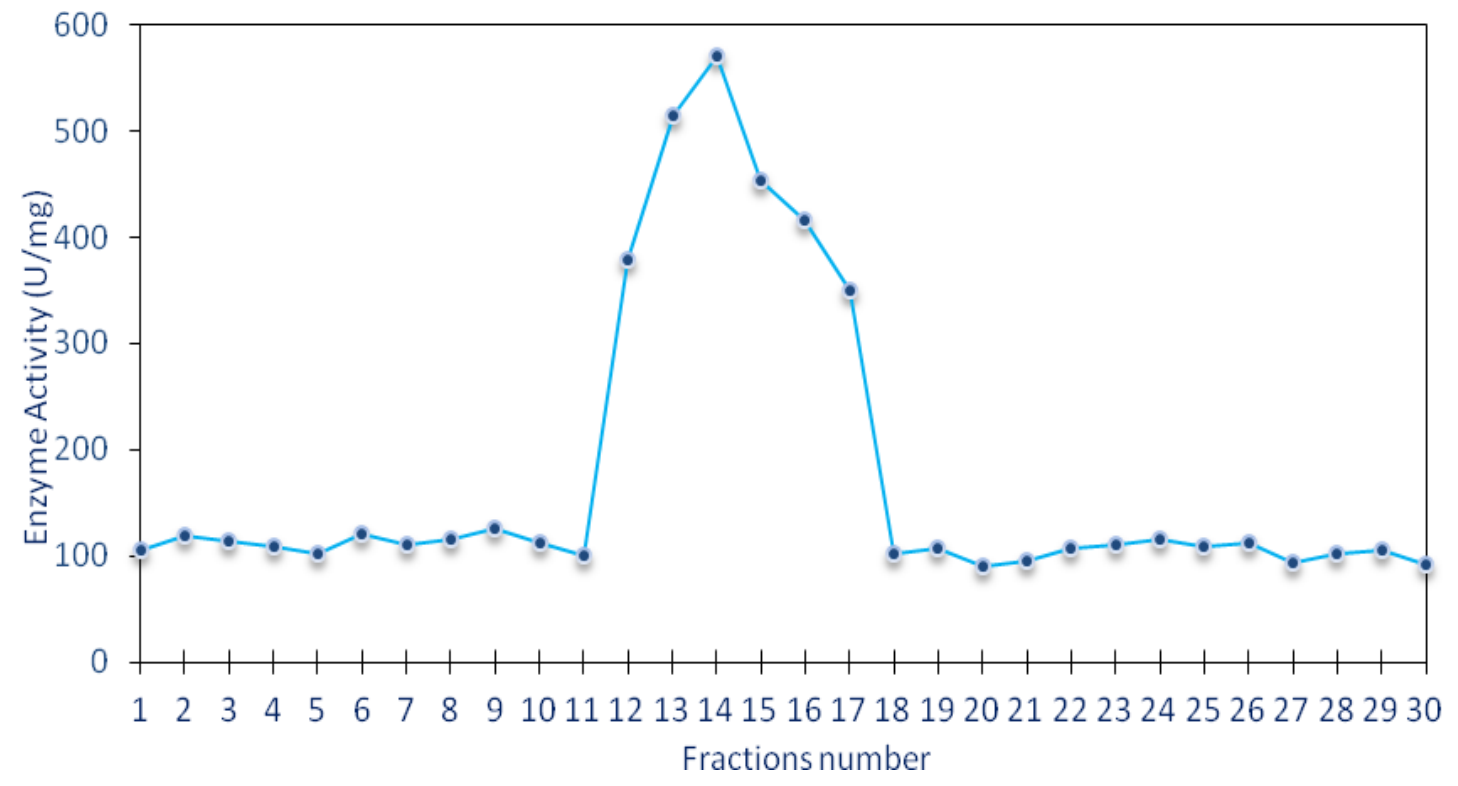

Figure 2. Gel filtration chromatographic purification profile for MnP from G. lucidum. 


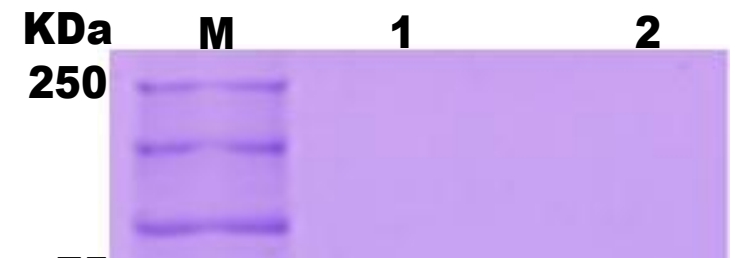

75

50

37

25

Figure 3. SDS-PAGE of $\mathrm{MnP}$ produced from $G$. lucidum IBL-05. The molecular mass of the purified $\mathrm{MnP}$ was estimated in comparison to standard protein marker, 25-250 kDa; (Sigma, USA). The protein bands were visualized by staining with Coomassie Brilliant Blue G-250.

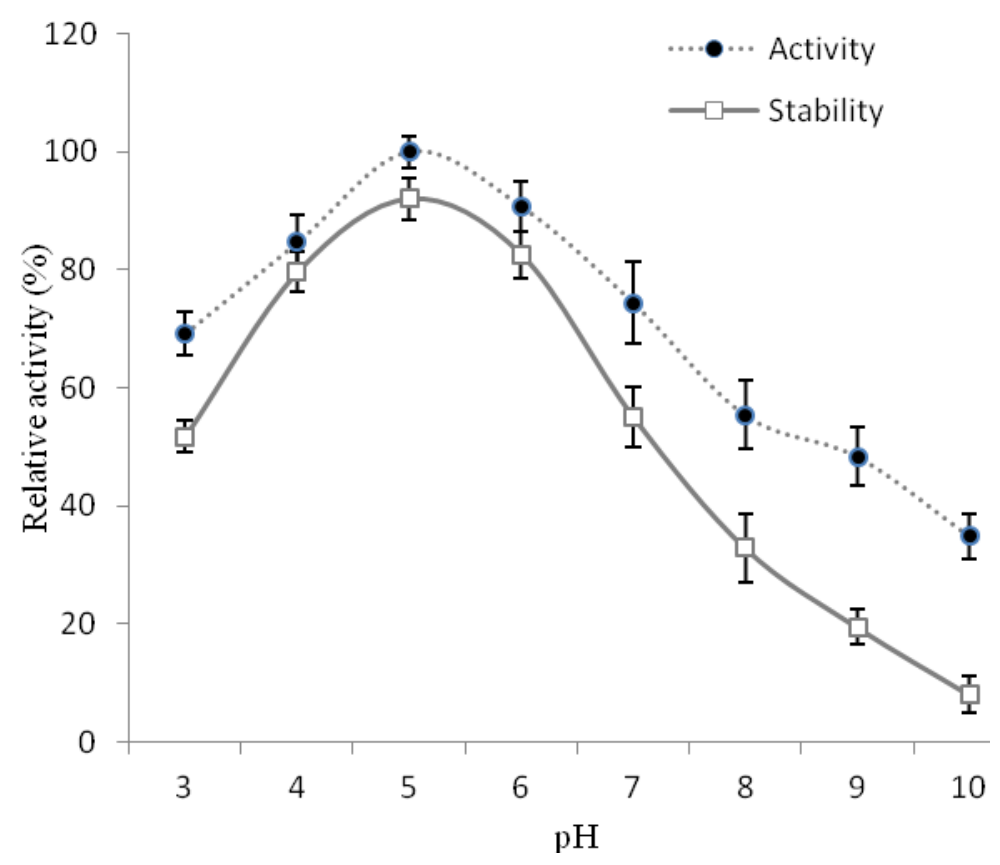

Figure 4. Effect of $\mathrm{pH}$ on the activity and stability of $\mathrm{MnP}$. The results presented arethe means of three independent experiments and the bars represent the standard deviation of the means. 


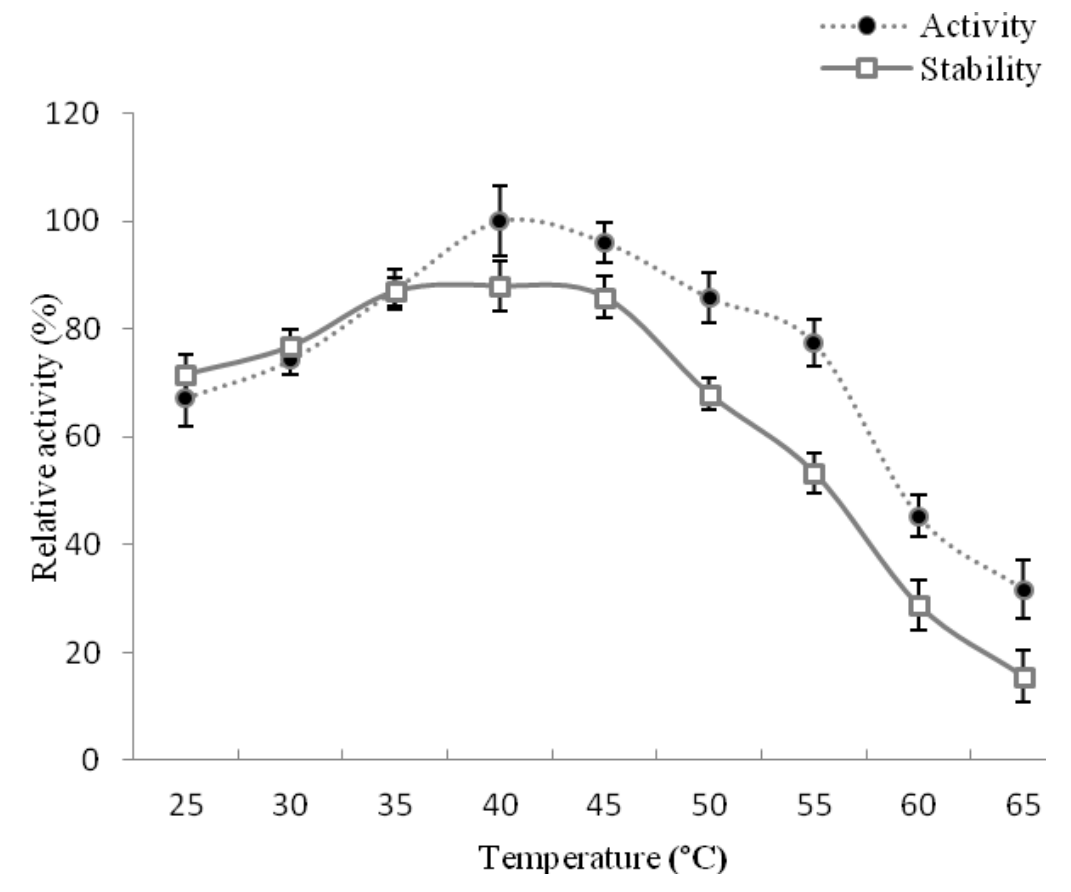

Figure 5. Effect of temperature on the activity and stability of MnP. The results are the means of three replicates and the bars represent the standard deviation of the means.

incubated at $55^{\circ} \mathrm{C}$ for $1 \mathrm{~h}$. The $\mathrm{MnP}$ isolated from different WRF demonstrated optimum temperature around 40 to $60^{\circ} \mathrm{C}$ (Hakala et al., 2005). The MnP from WRF strain, Irpex lacteus was stable in the temperature range of 30 to $40^{\circ} \mathrm{C}$ (Shin et al., 2005), while Rhizoctonia $\mathrm{sp}$. isolated $\mathrm{MnP}$ was deactivated over $55^{\circ} \mathrm{C}$ (Cai et al., 2010). The MnP2 isozyme from Lentinula edodes showed thermal-stability up to $40^{\circ} \mathrm{C}$ (Boer et al., 2006).

\section{Determination of kinetic constants $\mathrm{Km}$ and $\mathrm{Vmax}$}

The $K_{\mathrm{m}}$ and $V_{\max }$ values were calculated by intercepting line on $\mathrm{X}$-axis and $\mathrm{Y}$-axis of the reciprocal plot, respectively, using different concentration (0.1 to $1.0 \mathrm{mM})$ of $\mathrm{MnSO}_{4}$ as assay substrate (Figure 6). At $0.5 \mathrm{mM}$ $\mathrm{MnSO}_{4}$ concentration, the maximum MnP activity (859 $\mathrm{UmL}^{-1}$ ) was furnished with $K_{\mathrm{m}} 65.64 \mu \mathrm{M}$ and $V_{\max } 640$ $\mathrm{UmL}^{-1}$ using non-linear regression analysis at optimum $\mathrm{pH}$ and temperature. The difference in $K_{\mathrm{m}}$ values of $\mathrm{MnP}$ from different reported fungal species might be due to the genetic variations and substrate specificities among various species. The interaction of enzyme with its substrate was indicated through $K_{\mathrm{m}}$ values and a lower $K_{\mathrm{m}}$ value reflect high affinity of enzyme for its substrate and higher $V_{\max }$ indicated that small amount of enzyme can convert substrate into the product (Asgher et al., 2014).

\section{Effect of various modulators on activity of MnP}

In order to identify the nature of enzyme, the effects of various organic compounds and metal ions as possible inhibitors and activators on MnP activities were studied (Table 2). The results revealed that $\mathrm{Mn}^{2+}$ and $\mathrm{Cu}^{2+}$ enhanced the activity of $\mathrm{MnP}$ at all tested concentrations. The metal ion $\mathrm{Mn}^{2+}$ showed the most significant role to activate $G$. lucidum $\mathrm{MnP}$, which was consistent with the findings of Boer et al. (2006). In addition, low concentrations of $\mathrm{Co}^{2+}(5 \mathrm{mM})$ drive up $\mathrm{MnP}$ activity but at higher concentration of $\mathrm{Co}^{2+}(20 \mathrm{mM})$ a slight inhibition was observed (91\%). Elevated concentrations of $\mathrm{K}^{+}$ enhanced the $\mathrm{MnP}$ activity (117\%) but lower $\mathrm{K}^{+}$ concentrations $(5 \mathrm{mM})$ did not exert any effect on $\mathrm{MnP}$ activity. On the other hand, $\mathrm{Zn}^{2+}$ and $\mathrm{Fe}^{2+}$ partially inhibited the $\mathrm{MnP}$, whereas $\mathrm{MnP}$ activity was strongly inhibited by Ethylene diamine tetra acetic acid (EDTA) and cysteine and even $\mathrm{Hg}^{2+}$ fully inactivated $\mathrm{MnP}$ enzyme. The MnP from $P$. chrysosporium was inhibited by $\mathrm{NaN}_{3}, \beta$-mercaptoethanol and dithreitol, whereas cooxidants such as glutathione, un-saturated fatty acids and Tween 80 , significantly enhanced the MnP activity (Urek and Pazarlioglu, 2004). Trichophyton rubrum LSK-27 $\mathrm{MnP}$ was entirely inhibited by $\mathrm{Hg}^{2+}$, while $\mathrm{Fe}^{3+}, \mathrm{Ca}^{2+}$ and $\mathrm{Ni}^{2+}$ did not show any inhibitory effect on enzyme activity (Boer et al., 2006). 


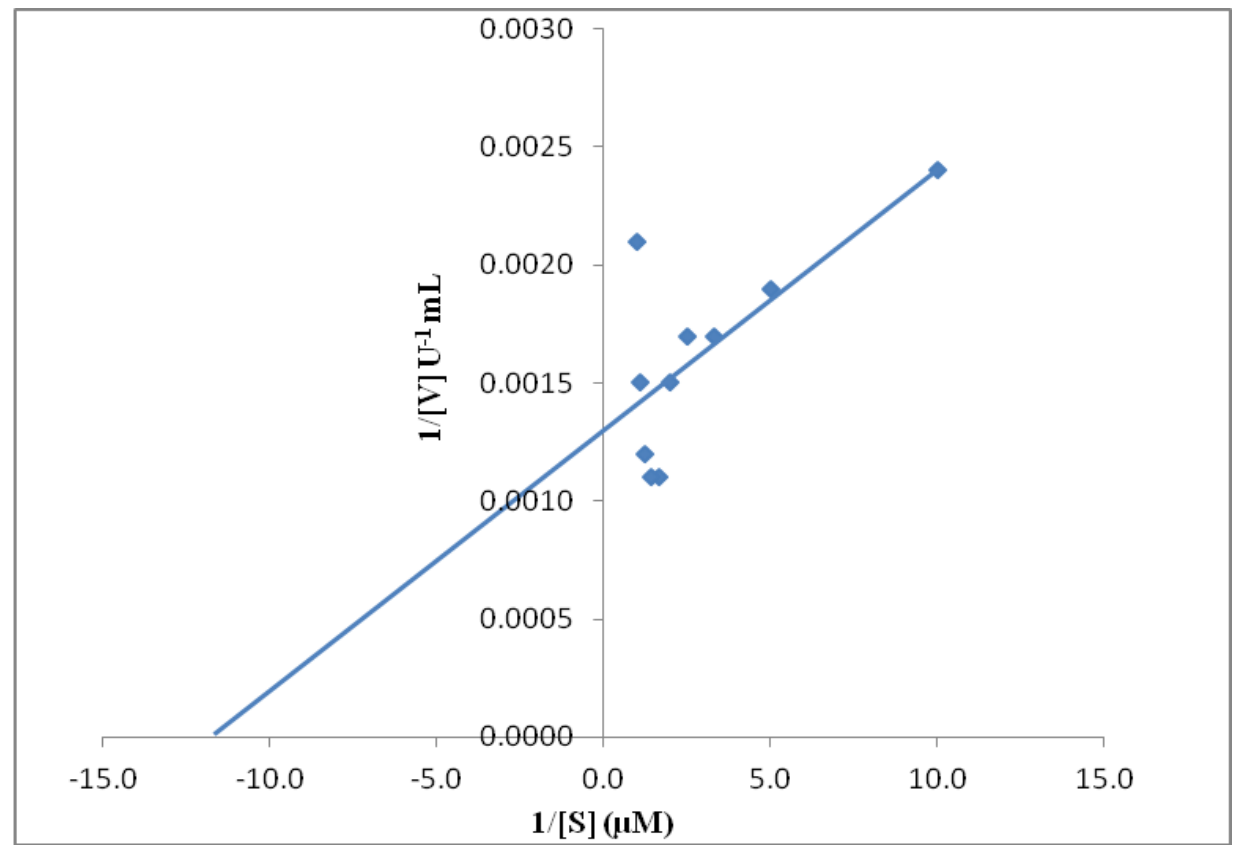

Figure 6. Lineweaver Burk Plot for determination of $K_{\mathrm{m}}$ and $V_{\max }$ for purified MnP.

Table 2. Effects of various modulators on the activity of purified MnP from G. lucidum.

\begin{tabular}{lcc}
\hline Modulators & Concentration $(\mathbf{m M})$ & Relative activity of $\mathbf{M n P}(\%)$ \\
\hline $\mathrm{Mn}^{2+}$ & 5 & $119 \pm 6.4$ \\
& 10 & $139 \pm 5.3$ \\
& 20 & $147 \pm 3.7$ \\
$\mathrm{Zn}^{2+}$ & 5 & $89 \pm 2.8$ \\
& 10 & $71 \pm 2.5$ \\
& 20 & $58 \pm 4.2$ \\
$\mathrm{Co}^{2+}$ & 5 & $109 \pm 5.1$ \\
& 10 & $103 \pm 4.6$ \\
& 20 & $91 \pm 4.7$ \\
$\mathrm{Cu}^{2+}$ & 5 & $114 \pm 4.5$ \\
& 10 & $117 \pm 3.9$ \\
& 20 & $128 \pm 4.9$ \\
$\mathrm{Fe}^{2+}$ & & \\
& 5 & $82 \pm 1.4$ \\
& 10 & $57 \pm 2.4$ \\
& 20 & $42 \pm 4.2$ \\
$\mathrm{Hg}^{2+}$ & & \\
& 5 & $14 \pm 0.9$ \\
& 10 & $7.6 \pm 0.13$ \\
$\mathrm{~K}^{2+}$ & 20 & $3.3 \pm 0.29$ \\
& & \\
& 5 & $101 \pm 4.0$ \\
& 10 & $109 \pm 3.9$ \\
& & $117 \pm 5.3$ \\
\hline
\end{tabular}


Table 2. Contd.

\begin{tabular}{lcc}
\hline & 5 & \\
EDTA & 10 & $45 \pm 1.9$ \\
& 20 & $32 \pm 2.3$ \\
& & $27 \pm 2.4$ \\
Cysteine & 5 & $38 \pm 1.7$ \\
& 10 & $21 \pm 2.1$ \\
\hline
\end{tabular}

All data are expressed in mean value \pm standard deviation.

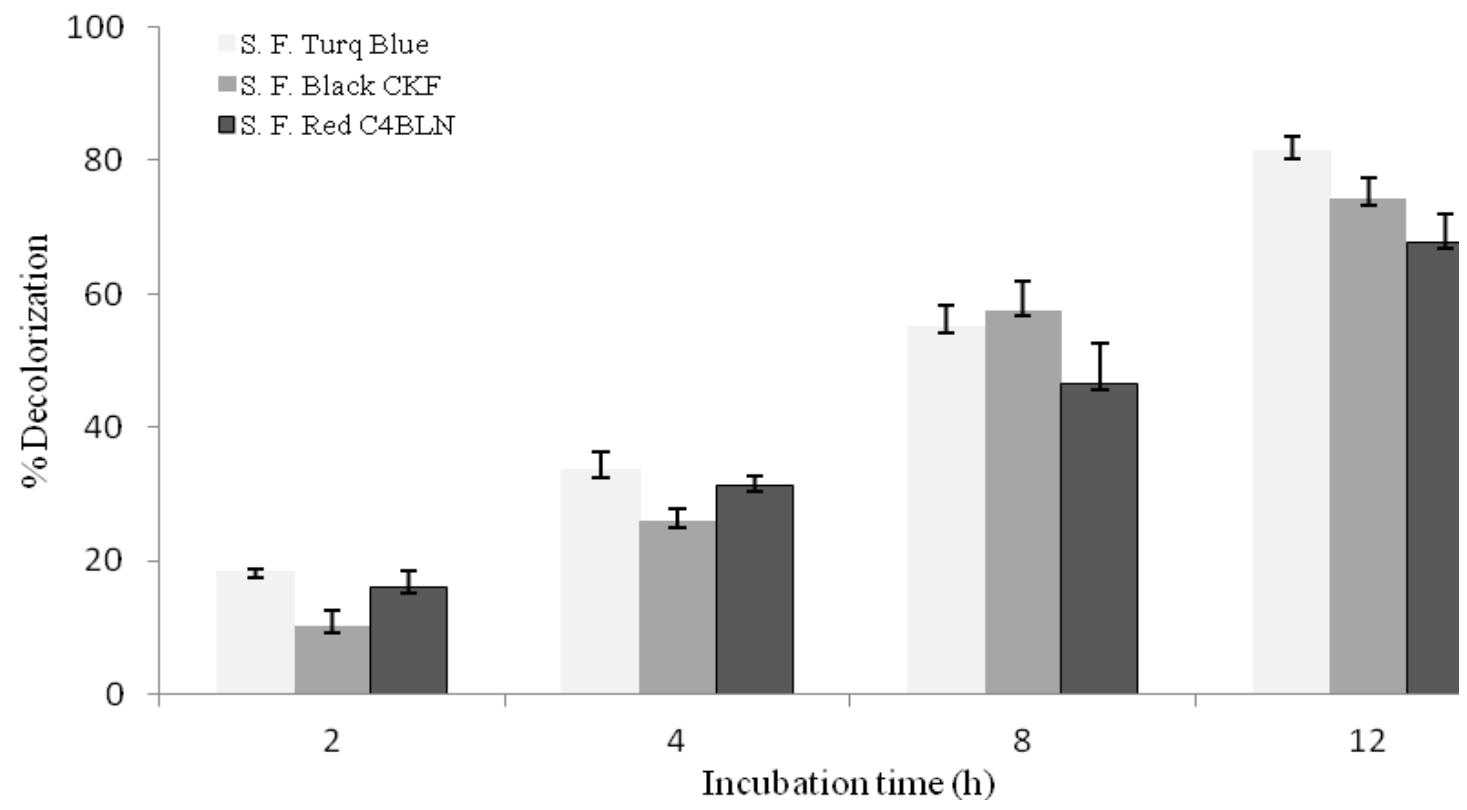

Figure 7. Percentage decolorization of textile dyes by purified MnP from G. Iucidum IBL-05. The results are the means of three replicates and the bars represent the standard deviation of the means.

\section{Decolorization of different textile (synthetic) dyes by purified MnP}

The dye-decolorizing potential of purified MnP from $G$. lucidum was demonstrated for different synthetic dyes (Sandal-reactive dyes) at different time periods. From data in Figure 7 it can be seen that MnP caused maximum decolorization of S.F. Turq Blue dye to $81.3 \%$, followed by S.F. Black CKF to $74.2 \%$ and S. F. Red $\mathrm{C}_{4} \mathrm{BLN}$ dye to $67.8 \%$ within $12 \mathrm{~h}$ of incubation period. The $\mathrm{MnP}$ was more effective for decolorization of different textile dyes including Remazol brilliant blue R (RBBR), Congo red, methylene blue and ethyl violet (Bazanella et al., 2013). The findings correlated with previous investigations (Cheng et al., 2007), which confirmed that $\mathrm{MnP}$ has remarkable catalytic potential to degrade and mineralize dyes and colored effluents. The peroxidases caused dye degradation by generating highly active free radicals such as $\mathrm{Mn}^{3+}$, lipid, hydroxyl, and peroxy-radicals (Hofrichter, 2002). However, the dyes are not uniformly susceptible to biodegradation because of the structural diversity (Murugesan et al., 2006).

\section{Conclusion}

The ion exchange and gel filtration column chromatography techniques were used to purify $\mathrm{MnP}$ enzyme from G. lucidum up to 3.43-fold. The molecular weight of purified $\mathrm{MnP}$ was determined to be $43 \mathrm{kDa}$ from SDS-PAGE analysis. Purified MnP showed encouraging activity and stability at their optimal $\mathrm{pH}$ and temperature. Further, the purified MnP possesses effective dye decolorization capability, indicating a useful tool for 
bioremediation purposes. The high level MnP production and its novel catalytic features suggest its suitability for industrial and biotechnological applications. Nevertheless, further molecular approaches are needed for improving its catalytic and thermal-stability characteristics that will be the focus of future research.

\section{Conflict of Interest}

The authors have not declared any conflict of interest.

\section{ACKNOWLEDGEMENT}

This study was supported by Higher Education Commission, Islamabad, Pakistan.

\section{REFERENCES}

Asgher M, Iqbal HMN (2011). Characterization of a novel manganese peroxidase purified from solid state culture of Trametes versicolor IBL-04. BioRes. 6:4302.

Asgher M, Irshad M, lqbal HMN (2013). Purification and characterization of novel manganese peroxidase from Schizophyllum commune IBL-06. Int. J. Agric. Biol. 15:749-754.

Asgher M, Shahid M, Kamal S, lqbal HMN (2014). Recent trends and valorization of immobilization strategies and ligninolytic enzymes by industrial biotechnology. J. Mol. Catal. B Enzymatic. 101:56-66.

Batool S, Asgher M, Sheikh MA, Rahma SU (2013). Optimization of physical and nutritional factors for enhanced production of lignin peroxidase by Ganoderma lucidum IBL-05 in solid state culture of wheat straw. J. Anim. Plant sci. 23(4):1166-1176

Boer CG, Obici L, Marques de Souza CG, Peralta RM (2006). Purification and some properties of Mn peroxidase from Lentinula edodes. Process Biochem. 41:1203-1207

Bradford MM (1976). "A rapid and sensitive method for quantification of microgram quantities of protein utilizing the principle of protein dye binding," Anal. Biochem. 72:248-254.

Cai Y, Wu H, Liao X, Ding Y, Sun J, Zhang D (2010). Purification and characterization of novel manganese peroxidase from Rhizoctonia sp. SYBC-M3. Biotechnol. Bioprocess Eng. 15:1016-1021

Cheng J, Shiqian R, Tang $L$ (2007). Purification of a new manganese peroxidase of the white-rot fungus Schizophyllum sp. F17 and decolorization of azo dyes by the enzyme. Enz. Microb. Technol. 41:258-264.

de Oliveira PL, Duarte MCT, Ponezi AN, Durrant LR (2009). Purification and partial characterization of manganese peroxidase from Bacillus pumilus and Paeni bacillus sp. Braz. J. Microbiol., 40:818-826.

Du J, Pu G, Shao C, Cheng S, Cai J, Zhou L, Jia Y, Tian X (2015). Potential of extracellular enzymes from Trametes versicolor F21a in Microcystis spp. Degradation. Mat. Sci. Eng. C 48(1): 138-144.

Ferhan M, Leao AL, de Melo IS, Yan N, Sain M (2012) Ligninases Production and Partial Purification of Mnp from Brazilian Fungal Isolate in Submerged Fermentation. Ferment. Technol. 1:106.
Giardina P, Palmieri G, Fontanella B, Rivieccio V, Sannia G (2000). Manganese peroxidase isoenzymes produced by Pleurotus ostreatus grown on wood sawdust, Arch. Biochem. Biophys. 376:171-179.

Hakala TK, Lundell T, Galkin S, Maijala P, Kalkkinen S, Hatakka A (2005). Manganese peroxidases, laccase and oxalic acid from the selective white-rot fungus Physisporinus rivulosus grown on spruce wood chips. Enz. Microbiol. Technol. 36:461-468

Hilden L, Johansson G, Pettersson G, Li J, Ljungquist P, Henrikson G (2000). Do the extracellular enzymes cellobiose dehydrogenase and manganese peroxidase form a pathway in lignin biodegradation? FEBS Lett. 477:79-83.

Hofrichter M (2002). Review: lignin conversion by manganese peroxidase (MnP). Enzyme Microb. Technol. 30:454-466.

Laemmli UK (1970). Cleavage of structural proteins during the assembly of the head of bacteriophage T4. Nature, 227:680-5.

Levin L, Herrmann C, Papinutti VL (2008). Optimization of lignocellulolytic enzyme production by the white-rot fungus Trametes trogii in solid-state fermentation using response surface methodology. Biochem. Eng. J. 39:207-214.

Martinez AT, Speranza M, Ruiz-Duenas FJ, Ferreira P, Guillen F, Martinez MJ, Gutierrez A, Rio CJ (2005). Biodegradation of lignocellulosics: microbial, chemical, and enzymatic aspects of the fungal attack of lignin. Int. J. Microbiol. 8:195-204.

Morgenstern I, Klopman S, Hibbett D (2008). Molecular evolution and diversity of lignin degrading heme peroxidases in the Agaricomycetes. J. Mol. Evol. 66:243-257.

Murugesan K, Nam I.-H, Kim Y.-M, Chang Y.-S (2007). Decolorization of reactive dyes by a thermostable laccase produced by Ganoderma lucidum in solid state culture. Enzyme Microb. Technol. 40:16621672.

Ramzan M, Asgher M, Sheikh MA, Bhatti HN (2013). Hyper-production of manganese peroxidase $(\mathrm{MnP})$ through chemical mutagenesis of Tremetes versicolor IBL-04 and optimization of process parameters. BioRes. 8:(3)3953-3966.

Reina R, Liers C, Ocampo JA, Garcia-Romera I, Aranda E (2013). Solid state fermentation of olive mill residues by wood-and dung-dwelling Agaricomycetes: Effects on peroxidase production, biomass development and phenol phytotoxicity. Chemosphere

Shin KS, Kim YH, Lim JS (2005). Purification and Characterization of manganese peroxidase of the white-rot fungus Irpex lacteus. J. Microbiol. 43:503-509.

Sylvia DJ, Lakshmi VJ, Devi PR (2015). Purification and Characterization of Manganese Peroxidase from Musa Acuminata Stem and Its Effect on Degradation of Dye Effluent. Int. J. Inn. Res. Sci. Eng. Tech. 4(5):2981-2987

Tien M, Kirk TK (1988). Lignin peroxidase of Phanerochaete chrysosporium. Methods Enzymol. 33:569-75.

Urek RO, Pazarlioglu NK (2004). Purification and partial characterization of manganese peroxidase from immobilized Phanerochaete chrysosporium. Process Biochem. 39:2061-2068

Wariishi H, Valli K, Gold MH (1992). Manganese (II) oxidation by manganese peroxidase from the basidiomycete Phanerochaete chrysosporium. Kinetic mechanism and role of chelators. J. Biol. Chem. 267:23688-23695. 